\title{
Myeloperoxidase (MPO) and eosinophil peroxidase (EPO) effecting on asthma patients in Basra Province, Iraq.
}

\author{
Shayma'a J. Raisan*, Muna H. Sadeq \\ Biology Department, College of Education for Pure Sciences, University of Basra, Basra, Iraq
}

\begin{abstract}
Myeloperoxidase and eosinophil peroxidase granules zurophilic proteins are a marker important in asthma patients. In the current study myeloperoxidase (MPO) and Eosinophil peroxidase levels were assessed in different stages of asthma, in $\mathbf{1 0 0}$ patients suffering from asthma, classified as (active asthma, moderate, and severe) according to diagnosis by specialist physician In addition to 20 healthy controls. Results of the current study showed mean serum level of MPO was $16.37 \pm 7.78 \mathrm{ng} / \mathrm{ml}$ (median \pm SD) in controls, and $39.80 \pm 22.22 \mathrm{ng} / \mathrm{ml}$ in the asthma patients. According to the asthma severity MPO levels were $(40.54 \pm 29.92,36.91 \pm 20.18$ and $34.42 \pm 16.04 \mathrm{ng} / \mathrm{ml})($ median \pm SD) in (active asthma, moderate, and severe) asthmatics patients, respectively with significant differences $(P \leq 0.05)$ between all type of asthma patients and healthy controls, according to asthma severity the results showed significant differences $(P \leq 0.05)$ between the type of asthma patients active asthma and severe asthmatics. On the other hand eosinophil peroxidase levels of EPO were $47.68 \pm 5.78 \mathrm{ng} / \mathrm{ml}$ (median \pm SD) in control and $75.89 \pm 14.46 \mathrm{ng} / \mathrm{ml}$ in the asthmatic patients. Depending on the asthma severity, the EPO levels were $76.81 \pm 11.45 \mathrm{ng} / \mathrm{ml}, 68.05 \pm 11.29 \mathrm{ng} / \mathrm{ml}, 66.19 \pm 11.77 \mathrm{ng} / \mathrm{ml}$ in active asthma, moderate, and severe asthmatics respectively, the results show no significant differences between the type of asthma patients $(P \geq 0.05)$, but show significant differences between the type of asthma patients and healthy controls and significant differences active asthma and severe asthmatics between $76.81 \pm 11.45,66.19 \pm 11.77 \mathrm{ng} / \mathrm{ml}$ respectively. Results of the study showed elevated levels of both enzymatic (EPO and MPO) respectively in asthma patients with active asthma with high significant different $(P \leq 0.01)$ compared with controls, while the results showed serum levels of EPO higher than MPO in patients.
\end{abstract}

Keywords: Asthma, Myeloperoxidase, Eosinophil peroxidase.

Accepted on September 22, 2018

\section{Introduction}

Asthma is a complex inflammatory disease that affects the airways is suffered by many people around the world, it is characterized by hyperhidrosis and excessive mucus secretion with other clinical symptoms [1,2]. Inflammatory processes is associated with the imbalance oxidative and antioxidants nature of the lungs a high level of oxygen so they are more susceptible to oxidative stress and the formation of free radicals and low activity of antioxidant enzymes [3]. The oxygen is the main element in the production of energy, but the reduction of this element is not complete even under normal conditions as often arise from the middle groups of active chemicals and called free radicals inflammatory response [4]. In asthma associated with the generation of free radicals (hydrogen peroxidase, $\mathrm{OH}^{-}$, superoxide anion $\mathrm{O}_{2}$, hypochlorous acid). This process regulates inflammatory mediator by inflammatory cells, such as eosinophilis, and neutrophils presence both cells causes tissue damage through the secretion of enzymatic products such as myloperoxidase, eosinophil peroxidase of neutrophils and eosinophilis cells respectively these enzymes production high-effective free radicals and oxidants that cause oxidative damage to the parasites and pathogens that invade the body as part of the innate defense mechanism of the host [5,6]. Myeloperoxidase and eosinophil peroxidase can react with $\mathrm{H}_{2} \mathrm{O}_{2}$ generated during a respiratory burst, and generating hypochlorous acid (HOCl), similar compounds that can cause injury to surrounding tissue during the inflammatory process [7]. So the study aims determination role of myeloperoxidase and eosinophil peroxidase in with asthma.

\section{Material and Methods}

\section{Patients}

A total of 100 asthma patient's and 20 control blood samples were collected from the Basra General Hospital, Al-Sadr General Hospital and, Al-Fayhaa General Hospital. The patients complaining of symptoms related wheezing, chest tightness, dyspnea attending, and all these patients were diagnosis by specialist physician. The patients and controls were from both sexes and their ages were from $(20 \mathrm{y}-70 \mathrm{y})$, Blood samples were collected from all asthma patients and 
controls in plain tube. $3 \mathrm{ml}$ of collected blood were centrifuged for $5 \mathrm{~min}(3000 \mathrm{rpm} / \mathrm{min})$, and kept in the refrigerator at a temperature of $-4^{\circ} \mathrm{C}$ for using in measuring the MPO and EPO enzyme by ELISA test.

\section{Serological study}

Estimation total MPO and EPO in serum sample of asthmatic patients: The total MPO and EPO concentration in the sera of studied individuals was determined by a micro plate enzyme immune assay according MPO and EPO Elisa kit (MyBioSource/USA). Before adding to wells, equilibrate the SABC working solution and TMB substrate for at least $30 \mathrm{~min}$ at room temperature $\left(37^{\circ} \mathrm{C}\right)$. When diluting samples and reagents, they must be mixed completely and evenly. Sufficient microtiter strips were left in the strip holder to enable the running of standards and samples. Add $(100 \mu \mathrm{l})$ of dilution buffer into the control (zero) well, the sample/standard (100 $\mu \mathrm{l})$ was Add into each well (except well 1), the plate was covered and incubated at $37^{\circ} \mathrm{C}$ for $90 \mathrm{~min}$, after that discard the plate content, clap the plate on the absorbent filter papers or other absorbent material, biotin-detection antibody working solution $(100 \mu \mathrm{l})$ was added into the above wells (standard, of test sample and zero wells), the plate was covered and incubated at $37^{\circ} \mathrm{C}$ for $60 \mathrm{~min}$, after that remove the cover, and wash plate 3 times with wash buffer. Promptly $(100 \mu \mathrm{l})$ of SABC working solution into each well (including well 1), cover the plate and incubate at $37^{\circ} \mathrm{C}$ for $30 \mathrm{~min}$, remove the cover and wash plate 5 times with wash buffer, and each time let the wash buffer stay in the wells for 1-2 min, Add $90 \mu$ of TMB substrate into each well, cover the plate and incubate at $37^{\circ} \mathrm{C}$ in dark within $15 \mathrm{~min}-30 \mathrm{~min}$, The reaction was stopped by adding $(50 \mu \mathrm{l})$ of stop solution into each well and mix thoroughly, the color changes into yellow immediately. The micro titer strips were shacked gently and read at $(450 \mathrm{~nm})$ (against the substrate blank) within $60 \mathrm{~min}$ from the stopping.

\section{Statistical analysis}

Statistical analysis is done by using SPSS software version 11, the chi square is used to assess statistical significance.

\section{Results}

The results showed that the concentration MPO in level $\leq 40$ $\mathrm{ng} / \mathrm{ml}$ had higher rat $(40.54 \pm 29.92,36.91 \pm 20.18,34.42 \pm$ 16.04) (median $\pm \mathrm{SD}$ ) in all asthma patients (active asthma, moderate and sever) respectively with significant difference $\mathrm{P}$ $\leq 0.05$ between asthma patients an $\mathrm{d}$ control, also the results show that concentration MPO in level $<40 \mathrm{ng}$ were increased in acute asthma subjects as compared to, moderate and severe asthma subjects Figure 1.

Also the result showed in Figure 2 that the concentration EPO level $\leq 50 \mathrm{ng} / \mathrm{ml}$ had higher rat in all type of asthma patients (active asthma, moderate and severe) (76.81 $\pm 11.45,68 \pm$ $11.29,66.19 \pm 11.77$ ) (median \pm SD) respectively, with significant difference $\mathrm{p} \leq 0.01$ between asthma patients an $d$ control, but the levels were not different between asthmatic patients.

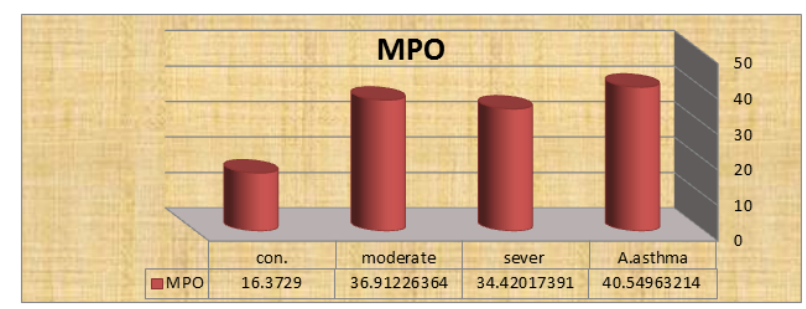

Figure 1. Differences concentration MPO in serum of asthma subjects and control group.

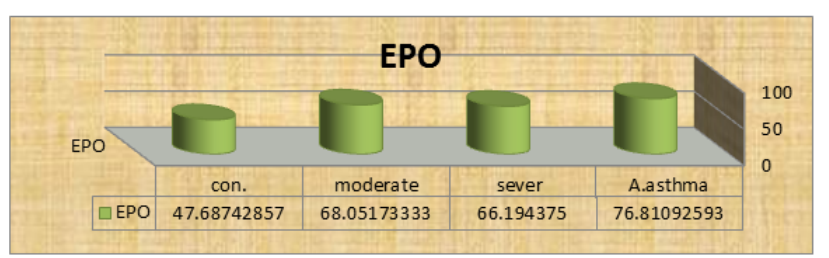

Figure 2. Differences in concentration EPO in serum of asthma subjects and control group.

In Figure 3 the study showed that the level of the enzyme EPO and MPO was higher in asthma patients $(75.89 \pm 14.46,39.80$ \pm 22.22 ) (median \pm SD) respectively with high significant difference with control. While the concentration of the enzyme EPO was higher than enzyme MPO the concentration in all type asthma patients.

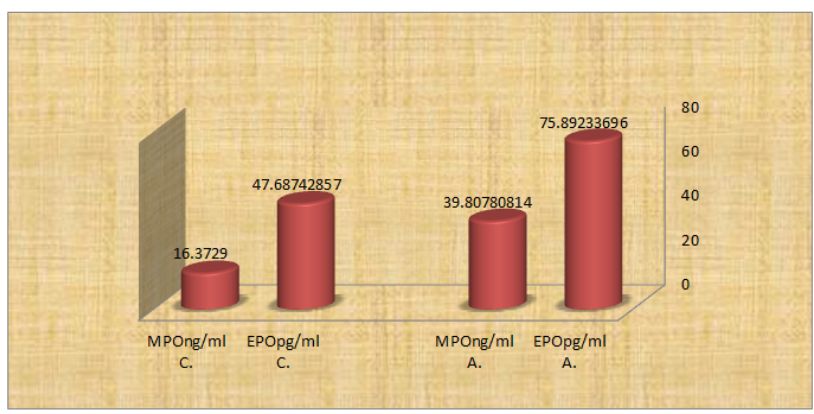

Figure 3. Correlations between enzyme (EPO) A concentration compared with (MPO) A enzyme in serum of asthma and control group ((EPO) $C$ and $(M P O) C$ ).

\section{Discussion}

Myeloperoxidase (MPO) and eosinophil peroxidase (EPO) enzymes produced from granular cells in inflammatory processes and increased severity of asthma. The current study showed that the concentration MPO had higher rat in active asthma compared with, moderate and severe asthma, Several studies have shown that neutrophils produce high amounts of the enzyme when exposed asthma, patients to antigens [8], also the study by [9] and showed that neutrophils cells release a high level of MPO in asthmatic patients compared to healthy. Also [10] found significant differences in the level of MPO in peripheral blood and neutrophil cells between patients and healthy patients. On the other hand the study by [11] showed 
that no significant differences in the level of MPO among asthma patients and control while In study by [12] reported that increased Neutrophils be in severe asthma patients. Authors showed that MPO used to distinguish between bacterial infections and viral infections in asthma patients [13]. Also the result showed that EPO had higher rat in active asthma compared with, moderate and severe asthma, many data found that the enzyme eosinophil peroxidase was responsible for producing hypobromous acid in the airways. The results of this study were agreed with [11] showed that the concentration of EPO is higher compared to healthy subjects, another study by [14] show that eosinophil peroxidase produces substantial amounts of hypobromous acid in the airways of stable asthmatics. Although this highly reactive oxidant is a strong candidate for exacerbating inflammatory tissue damage in the lung, its role in asthma remains. The EPO and MPO play important role in forming oxidants and their ability oxidative damage to pathogen and host tissue, eosinophil peroxidase and myeloperoxidase use hydrogen peroxide to produce hypobromous acid and hypochlorous acid. These powerful oxidants may damage the lungs if they are produced as part of the inflammatory response in asthma [15]. Also [16] showed that eosinophils and neutrophils generate an array of oxidants that may be important contributors to tissue damage in the airways also [17] showed that oxidized by peroxidases to produce a much stronger oxidant.

\section{Conclusion}

The results of this study show correlation of myeloperoxidase and eosinophil peroxidase with asthma pathogenesis indicates that it is important to evaluate myeloperoxidase and eosinophil peroxidase in allergic asthma patients.

\section{References}

1. Turato G, Baraldo S, Zuin R, Saetta M. The laws of attraction: chemokines, neutrophils and eosinophils in severe exacerbations of asthma: a possible new therapeutic strategy for preventing exacerbations. Thorax 2007; 62: 465-466.

2. Murphy DM, OByrne PM. Recent advances in the pathophysiology of asthma. Chest 2010; 137: 1417-1426.

3. Voynow JA, Kummarapurugu A. Isoprostanes and asthma. Biochimica et Biophysica Acta 2011; 1810: 1091-1095.

4. Comhair SA, Erzurum SC. Redox control of asthma: molecular mechanisms and therapeutic opportunities. Antioxidants Redox Signal 2010; 12; 93-124.

5. Dworski R. Oxidant stress in asthma. Thorax 2000; 55: 51-53.

6. MacPherson JC, Comhair SA, Erzurum SC, Klein DF, Lipscomb MF, Kavuru MS, Samoszuk MK, Hazen SL.
Eosinophils are a major source of nitric oxide-derived oxidants in severe asthma: characterization of pathways available to eosinophils for generating reactive nitrogen species. J Immunol 2001; 166: 5763-5772.

7. Hargreave FE, Nair P. The definition and diagnosis of asthma. Clin Exp Allergy 2009; 39: 1652-1658.

8. Gibson PG, Simpson JL, Saltos N. Heterogeneity of airway inflammation in persistent asthma: evidence of neutrophilic inflammation and increased sputum interleukin-8. Chest 2001; 119: 1329-1336.

9. Monteseirin J, Bonilla I, Camacho J, Conde J, Sobrino F. Elevated secretion of myeloperoxidase by neutrophils from asthmatic patients. The effect of immunotherapy. Mosby Incdoi 2001.

10. Monteseirin J. Neutrophils and asthma. Esmonpublicidad 2009; 19: 340-354.

11. Aldridge RE, Chan T, Van dalen CJ, Senthilmohan R, Winn M, Per V, Town GI, Kettle AJ. Eosinophil peroxidase produces hypobromous acid in the airways of stable asthmatics. Elsevier Science Inc. 2002.

12. Uddin M, Nong G, Ward J, Seumois G, Prince LR, Wilson SJ, Cornelius V, Dent G, Djukanovic R. Prosurvival activity for airway neutrophils in severe asthma. Thorax 2010; 65: 684-689.

13. Tauber E, Herouy Y, Urbanek R, Goetz M, Hagel E. Assessment of serum myeloperoxidase in children with bronchial asthma. Eur J Allergy Clin Immunol 2001.

14. Ruth EAT, Christine JVD, Alen RS, Marti G, Aony J. Eosinophil peroxidase roduces hypobromous acid in the airways of stable asthmatics. J Free Rad Biol Med 2002; 33: 847-856.

15. Faurschou M, Borregaard N. Neutrophil granules and secretory vesicles in inflammation. Microbes Infect 2003; 5: 1317-1327.

16. Mitra SNS, Hazen ASL. Role of eosinophil peroxidase in the origins of protein oxidation in asthma. Redox Rep 2000; 5: 215-224.

17. Van Dalen CJ, Kettle AJ. Substrates and products of eosinophil peroxidase. Biochem J 2001; 358: 233-239.

\section{*Correspondence to}

Shayma'a. J. Raisan

Biology Department

College of Education for Pure Sciences

University of Basra

Iraq 